Estudios de

lingüística inglesa aplicada

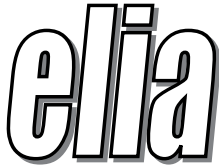

\title{
MYTHS AND CHALLENGES ON RAISING BILINGUAL CHILDREN IN ENGLISH BY NON-NATIVE PARENTS IN SPAIN
}

\section{RETOS Y MITOS SOBRE LA CRIANZA BILINGÜE ESPAÑOL- INGLÉS POR NO NATIVOS}

\author{
Laura Lozano-Martínez \\ CEIP Francisco de Quevedo y Villegas, Villasevil (Cantabria) \\ Doctoranda en Filología, UNED \\ 1lozano23@alumno.uned.es
}

DOI: http://dx.doi.org/10.12795/elia.mon.2019.i1.10

English has become a lingua franca in most international settings. Citizens in a globalized world need multilingual profiles in order to enhance their employability (Baker, 2011). Consequently, Spanish-English bilingual programmes have proliferated in Spain to meet such requirements (LozanoMartínez, 2017). In order to foster their children's learning experience, some Spanish non-native English-speaking parents have decided to speak to their children in English. Thus, family language planning is crucial to children's linguistic development. When the socialization scope of the baby goes beyond the family, children's language awareness is progressively weakened (Zhao, 2018). In this way, what are the challenges? Which preconceived ideas prevent some parents from trying or reinforcing their language planning endeavour? What kind of support is needed, or available, in order to complete an input based on the 'one person-one language' strategy (OPOL) which, according to De Houwer (2007) is not enough on its own? In this sense, there are only a few references like those of Saunders (1988) and Jernigan (2015)

ELIA Mon. I, pp. 235-264 DOI: http://dx.doi.org/10.12795/elia.mon.2019.i1.10 
about non-native speakers who raise their children bilingually. We come across even less references about studies contextualized in Spain as that by Sánchez Torres (2010). Further studies are needed. This paper aims to identify the aforementioned challenges and myths, by means of the quantitative analysis of the data obtained from a questionnaire fulfilled by 735 families that allows us to describe the present scenario.

Key words: Raise, bilingual, non-native, children, family

El inglés se erige como lingua franca en la mayoría de contextos internacionales. Los ciudadanos de este mundo globalizado necesitan perfiles multilingües que aumenten su empleabilidad (Baker, 2011) por lo que en España los programas de educación bilingüe español-inglés han proliferado para atender a dicha necesidad (Lozano-Martínez, 2017). Con el fin de contribuir, algunos padres y madres españoles hablan en inglés a sus hijos sin ser nativos. Así, la planificación lingüística familiar es crucial para el desarrollo lingüístico, se comienza con los bebés pero al añadir ámbitos de socialización, además del familiar, su consciencia sobre la lengua extranjera se va debilitando (Zhao, 2018). Por tanto ¿cuáles son los retos? ¿qué ideas preconcebidas disuaden a algunos de intentarlo o persistir? ¿Qué apoyos se precisan o están disponibles para complementar un input basado en la estrategia 'una persona-una lengua' que según (De Houwer, 2007) no es suficiente? En este sentido, encontramos pocas referencias destacando Saunders (1988) y Jernigan (2015) sobre no nativos que crían en una lengua extranjera a sus hijos para que sean bilingües. Menos aún sobre estudios contextualizados en España como el de Sánchez Torres (2010). Resulta necesario investigar al respecto. Este articulo pretende identificar los referidos retos y mitos, mediante el análisis cuantitativo de los datos obtenidos a partir de un cuestionario a 735 familias que permite describir el escenario que nos situamos.

Palabras clave: Crianza, bilingüe, no nativos, hijos, familia

\section{Introduction and Justification}

The English language enjoys undoubtedly a prominent position internationally as a global language, as an international language and as a lingua franca, in spite of the fact that there is no consensus on the concrete definition of these terms, as their meanings in fact overlap (Illés, 2018). Nowadays, regardless of people's academic background, it is commonly agreed that English is a must

ELIA Mon. I, pp. 235-264 DOI: http://dx.doi.org/10.12795/elia.mon.2019.i1.10 
for any job application. Nevertheless, EU member states have been urged to promote the learning of at least three European languages including their own in order to increase citizens' mobility and employability (Department of Education, 1995). The main role of the English language in Spain is evidenced by the proliferation of bilingual programmes (Lozano-Martínez, 2017). According to the English Impact Report (Shepherd \& Ainsworth, 2017) bilingual programmes improve the levels of students' linguistic competence in English; it seems clear that students who are enrolled in a bilingual programme learn the English language better than those in mainstream schools due to a higher amount of linguistic input (Pérez-Cabello, in Rius, 2018). On the other hand, parents strive to help their children by hiring private language tutors, paying for lessons in language institutes and trips abroad so their children have more opportunities to improve their communicative competence in English (Chacón Beltrán, in Rius, 2018). Moreover, some parents, without being native speakers of the English language, have decided to raise their children in English. But what are the challenges of raising bilingual children in a foreign language? Are there any myths on raising a child bilingually? What are the most prominent fears? This article aims to provide possible answers to these questions.

\section{Bilingual Parenting by Non-native Speakers}

Despite the many possible interpretations, in this article I use the expression 'bilingual parenting by non-native speakers' in relation to raising children in a family unit in which its members are using a foreign language that is not the mother tongue or the main language of either parent.

However, in some cases, a language that is foreign to the parents might become the mother tongue of the children by means of frequent use, until the children start school and are involved in more socialising activities, at the same time that their awareness of the foreign language is weakened (Zhao, 2018). This usually happens at three years of age.

The core interest in this study includes Spanish parents who raise their children bilingually in English-Spanish without the English language being the mother tongue of either parent, so their level of linguistic competence in English might vary considerably, as well as the frequency in the use of the English language in the family setting.

ELIA Mon. I, pp. 235-264 DOI: http://dx.doi.org/10.12795/elia.mon.2019.i1.10 


\section{The Study}

\subsection{Objectives}

This article stems from a preliminary study on children being raised bilingually in a foreign language by non-native parents. It is based on a study that targets the identification of the challenges and some of the myths that surround such a type of parenting.

We have also carried out the pertinent statistic tests in order to find out whether there is a correlation between families' perceptions of the challenges and myths about bilingual parenting by non-native speakers and their competence in spoken English. We have also attempted to find out whether such perceptions are determined by the use of English at home or not.

\subsection{Informants}

735 families have participated in this study. They represent different types of family structures: single parents, same-sex and opposite-sex parents, with different academic and professional backgrounds and a varied number of children of different ages. Thus, families in this study are heterogeneous and live in different regions of Spain, including urban as well as rural areas, and with different population densities. We endeavoured to come up with a representative sample.

$45,7 \%$ of the 735 participant families use English or they have used it for some time, 54,3\% do not use English at all. In the following section, we present the analysis of the data and we provide a discussion (table 1).

ELIA Mon. I, pp. 235-264 DOI: http://dx.doi.org/10.12795/elia.mon.2019.i1.10 


\begin{tabular}{|c|c|c|c|c|c|}
\hline \multicolumn{2}{|c|}{} & Frequency & Percent & Valid percent & $\begin{array}{c}\text { Cumulative } \\
\text { percent }\end{array}$ \\
\hline \multirow{4}{*}{ Valid } & Abandoned & 94 & 12,8 & 12,8 & 12,8 \\
\cline { 2 - 6 } & No & 399 & 54,3 & 54,3 & 67,1 \\
\cline { 2 - 6 } & Yes & 210 & 28,6 & 28,6 & 95,6 \\
\cline { 2 - 6 } & My partner & 32 & 4,4 & 4,4 & 100,0 \\
\cline { 2 - 6 } & Total & 735 & 100,0 & 100,0 & \\
\hline
\end{tabular}

Table 1. Do you speak English to your children?

\subsection{Procedure}

The final version of the questionnaire resulted from a previous phase of bibliographic search and reading, as well as from ideas steamed from informal conversations held with different families with the intention of selecting the most important questions and of determining the variables.

The questionnaire was piloted twice. It was first piloted among 18 families, so we could delete, add and readjust some questions. Then we piloted the questionnaire again among 104 families, so we could make different readjustments and get a final version of the questionnaire.

\subsection{Variables}

The main variable in this study is the level of competence in English of the informant parent. As a contrastive factor, we have chosen the level of oral production in English because this is an essential skill when raising children. Besides, some authors mention that oral production (speaking) gets the worst results in the learning of English (Levy, 2018). We can observe the distribution of the 735 participants according to their level of spoken English in Table 2.

ELIA Mon. I, pp. 235-264 DOI: http://dx.doi.org/10.12795/elia.mon.2019.i1.10 


\begin{tabular}{|c|c|c|c|c|c|}
\hline \multicolumn{2}{|c|}{} & Frequency & Percent & $\begin{array}{c}\text { Valid } \\
\text { percent }\end{array}$ & $\begin{array}{c}\text { Cumulative } \\
\text { percent }\end{array}$ \\
\hline \multirow{7}{*}{ Valid } & 1,0 (No level) & 76 & 10,3 & 10,3 & 10,3 \\
\cline { 2 - 6 } & $2,0(\mathrm{~A} 2)$ & 172 & 23,4 & 23,4 & 33,7 \\
\cline { 2 - 6 } & $3,0(\mathrm{~B} 1$ & 185 & 25,2 & 25,2 & 58,9 \\
\cline { 2 - 6 } & $4,0(\mathrm{~B} 2-\mathrm{C} 1)$ & 201 & 27,3 & 27,3 & 86,3 \\
\cline { 2 - 6 } & $5,0(\mathrm{C} 2)$ & 101 & 13,7 & 13,7 & 100,0 \\
\cline { 2 - 6 } & Total & 735 & 100,0 & 100,0 & \\
\hline
\end{tabular}

Table 2. Level of spoken English of the informant parent.

\subsection{Data Analysis and Discussion}

In the following lines, we analyse the data obtained in relation to the potential myths to be identified, and we discuss their identification.

\section{- Myths}

The objective of raising children bilingually is to make them sound like native English speakers

Most families and students prefer native teachers of English. It is commonly accepted that the native speaker is considered a model learners look up to, so the informants were asked whether they thought sounding like a native speaker of English was an objective when raising children bilingually. 83,3\% partially or totally agree with this statement (Figure 1).

ELIA Mon. I, pp. 235-264 DOI: http://dx.doi.org/10.12795/elia.mon.2019.i1.10 


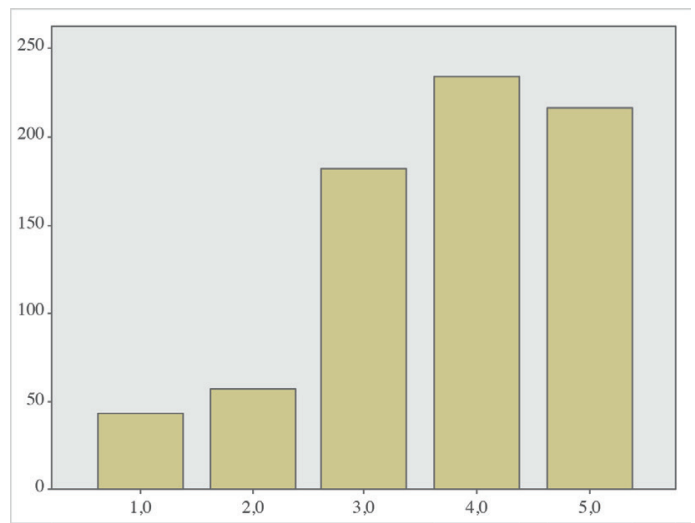

Figure 1. To sound native-like as an objective.

Pearson's Chi-square test using Statistical Package for the Social Science (SPSS) shows that the objective of sounding like a native speaker of English does not depend on the informant's level of spoken English $(\mathrm{p}=0.745)$, rather, it is a general perception.

In this sense, we would like to mention that in spite of the fact that there is no consensus on the concept and exact definition of Native Speaker (NS) (Chacón Beltrán, 2017) we tend to attribute some qualities to the Native Speaker that surpass those of an average Native Speaker (White \& Genesee, 1996) (Chacón Beltrán, 2017) and we usually think of an educated Native Speaker. However, we cannot assume that the Native Speaker masters his/her own language just because he/she is native (Chacón Beltrán, 2017) whilst disregarding his/her linguistic and academic background.

\section{My non-native pronunciation damages my child's proficiency in English}

Non-native speakers are worried $(67,8 \%)$ because they think that their nonnative pronunciation might affect their children's level of English. However, this perception directly depends on the informant's level of spoken English, according to the Chi-square test (table 3). Thus, worries are inversely proportional to the informant's level of English. 


\begin{tabular}{|c|c|c|c|}
\hline \multicolumn{4}{|c|}{ Chi-square test } \\
\hline & Value & Df & $\begin{array}{c}\text { Asymptotic } \\
\text { significance } \\
\text { (2-sided) }\end{array}$ \\
\hline Pearson's chi-square & $105,784^{\mathrm{a}}$ & 16 &, 000 \\
\hline Likelihood Ratio & 100,529 & 16 &, 000 \\
\hline Linear-by-Linear & 64,236 & 1 &, 000 \\
\hline $\mathrm{N}$ of valid cases & 735 & & \\
\hline \multicolumn{4}{|c|}{$\begin{array}{l}\text { a. } 0 \text { cells }(0,0 \%) \text { have expected count less than } 5 \text {. The minimum expected } \\
\text { count is } 12,10 \text {. }\end{array}$} \\
\hline
\end{tabular}

Table 3. Concerns about non-native pronunciation and level of English.

When non-native speakers stop worrying about their linguistic performance, their proficiency may actually increase (Ghlamallah, 2015). Furthermore, the concept of a bilingual person being the sum of two monolinguals was debunked by various studies carried out in the $60 \mathrm{~s}$ (Ghlamallah, 2015).That idea pertained to an idealized concept of 'balanced bilingualism' that is almost never achieved, since "rarely is anyone equally competent in one or more languages across all situations" (Baker, 2011: 8). Thus, non-native speakers' worrying about their proficiency may affect their self-confidence, because by idealizing monolingual native speakers they realize that they cannot always match native speaker proficiency. In addition to affecting their self-esteem, this may also impede their achieving higher proficiency in the foreign language they are learning.

\section{My mistakes will become fossilised in my child's repertoire so they will find it difficult to eradicate them}

The fossilization of mistakes is frequent in the learning of a foreign language, while it does not occur in the mother tongue (Myles, 2002). Nevertheless, mistakes are learnt the same way as correct patterns, by means of the same processes (Brown, 2000). There is a risk of fossilisation of errors when these are not corrected (López García, 2016). The main problem when non-native speakers are raising children bilingually in a second language (L2) is that their children might be exposed to linguistic 
errors. Passing errors do not necessarily worsen children's level of English but when errors are fossilised they become permanent (Sánchez Iglesias, 2011) which seems to be a concern for the $65,3 \%$ of the informant families. The intensity of the concern definitely depends on the informant's level of English (p-value=0), as Pearson's chi-square test show (table 4).

\begin{tabular}{|c|c|c|c|}
\hline & Value & Df & $\begin{array}{c}\text { Asymptotic } \\
\text { significance } \\
\text { (2-sided) }\end{array}$ \\
\hline Pearson's chi-square & $50,113^{\mathrm{a}}$ & 16 &, 000 \\
\hline Likelihood Ratio & 49,021 & 16 &, 000 \\
\hline Linear-by-Linear & 36,168 & 1 &, 000 \\
\hline N of valid cases & 735 & & \\
\hline $\begin{array}{l}\text { b. 0 cells }(0,0 \%) \text { have expected count less than } 5 . \\
\text { The minimum expected count is 11,89. }\end{array}$ \\
\hline
\end{tabular}

Table 4. My son/daughter will fossilise my errors.

\section{The parent-child relationship might be affected by being raised in a foreign language by non-native speakers}

Bowlby (1985) stated there is always a bond between parents and children and 'the attachment relationship acts as a prototype for all future social relationships so disrupting it can have severe consequences' (McLeod, 2017). Secure attachment between a primary caregiver and the child is essential for a healthy psychological development. The attachment style (secure - unsecure) might determine the mental health of the child and of the future adult (Bowlby, 1951).

Regarding bilingualism specifically, will attachment be affected by raising children bilingually by non-native speakers? According to the descriptive analysis it is not a concern for the $66,8 \%$ of the informant families (table 5), and such a perception does not depend on the informant's level of English of ( $p$-value=0,618).

ELIA Mon. I, pp. 235-264 DOI: http://dx.doi.org/10.12795/elia.mon.2019.i1.10 


\begin{tabular}{|c|c|c|c|c|c|}
\hline \multicolumn{2}{|c|}{} & Frequency & Percent & Valid percent & $\begin{array}{c}\text { Cumulative } \\
\text { percent }\end{array}$ \\
\hline \multirow{7}{*}{ Valid } & 1,0 & 375 & 51,0 & 51,0 & 51,0 \\
\cline { 2 - 6 } & 2,0 & 116 & 15,8 & 15,8 & 66,8 \\
\cline { 2 - 6 } & 3,0 & 103 & 14,0 & 14,0 & 80,8 \\
\cline { 2 - 6 } & 4,0 & 74 & 10,1 & 10,1 & 90,9 \\
\cline { 2 - 6 } & 5,0 & 67 & 9,1 & 9,1 & 100,0 \\
\cline { 2 - 6 } & Total & 735 & 100,0 & 100,0 & \\
\hline
\end{tabular}

Table 5. Bilingual raising (L1, L2) and attachment.

\section{If my child mixes languages something is going wrong}

It could be thought that when children are learning foreign languages they might get confused so it is interesting to analyse the practice of mixing languages (codemixing) which implies the use of more than one language in a conversation or even in the same sentence (Richards \& Schmidt, 2013). However, the descriptive analysis shows that $83,7 \%$ do not consider the combined use of foreign languages as evidence of a problem (figure 2). Thus said, Chi-square test of Independence indicate that there is a significant relationship ( $p$-value $=0,000)$ between the informant's level of spoken English and his/her perception about such a phenomenon. Data reflect that the higher the informant's level of English, the lower the perception of codemixing to be a problem.

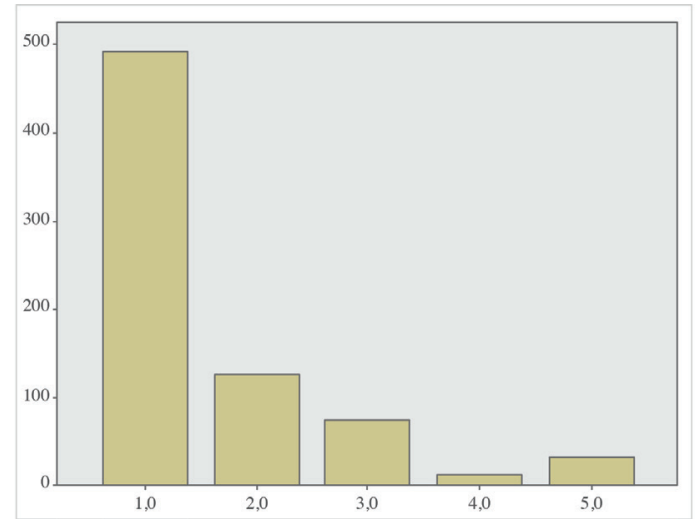

Figure 2. Mixing languages as evidence of a problem. 


\section{- Challenges}

Raising children in a foreign language is a complex endeavour. Once fears are overcome and a decision is made, despite preconceived ideas or assumed myths, some challenges are unavoidable. At this juncture, some of such challenges have been analysed though more empirical research needs to be carried out on this.

\section{Lack of authoritative sources on how to raise children bilingually being a non-native speaker}

The first step can be hard to take due to the lack of reliable sources of information about how to raise a child bilingually when none of the parents is a native speaker of the second language, as $59,4 \%$ of the informants state. We have noted the scarcity and lack of academic and scientific literature about non-native parents raising their children bilingually. Searching for bibliographic references about Spanish people living in Spain and raising their children bilingually without being native speakers of the English language produces even less results. I obtained but a few references. We can find an interesting study about 30 families in Seville (three of them were non-native families) by Sánchez Torres (2010) whose conclusions are insightful and serve as a starting point for further research.

However, there are other sources of information, despite their lack of academic and scientific foundation which can be helpful in guiding the research procedure. These refer to personal experiences that are shared in blogs and on social media.

Statistical tests indicate that those informants with an excellent command of English have less concerns about the lack of bibliographic sources on bilingual raising by non-native speakers ( $p$-value $=0,000$ ). Thus, informants at a $\mathrm{C} 2$ level prove themselves to be more independent on such a type of source (table 6).

ELIA Mon. I, pp. 235-264 DOI: http://dx.doi.org/10.12795/elia.mon.2019.i1.10 


\begin{tabular}{|c|c|c|c|c|c|c|c|}
\hline \multicolumn{8}{|c|}{ Crosstabulation } \\
\hline \multicolumn{8}{|c|}{ Count } \\
\hline \multirow{2}{*}{\multicolumn{2}{|c|}{1,0}} & \multicolumn{6}{|c|}{$\begin{array}{l}\text { Lack of well-founded sources about bilingual } \\
\text { raising by non-native speakers }\end{array}$} \\
\hline & & 2,0 & 3,0 & 4,0 & 5,0 & Total & \\
\hline \multirow{5}{*}{ Level of spoken English } & 1,0 & 8 & 11 & 19 & 10 & 28 & 76 \\
\hline & 2,0 & 9 & 19 & 59 & 41 & 44 & 172 \\
\hline & 3,0 & 25 & 25 & 57 & 34 & 44 & 185 \\
\hline & 4,0 & 26 & 38 & 66 & 42 & 29 & 201 \\
\hline & 5,0 & 28 & 13 & 39 & 13 & 8 & 101 \\
\hline \multicolumn{2}{|l|}{ Total } & 96 & 106 & 240 & 140 & 153 & 735 \\
\hline
\end{tabular}

Table 6. Level of English * lack of information as an obstacle.

\section{Lack of fluency in English}

Evidently, those who lack fluency in English are more reluctant to use it with their children due to the difficulties that arise, which is reflected in Pearson's chi-square test ( $p$-value $=0,0)($ Table 7$)$. Lack of fluency might be an obstacle for communication.

\begin{tabular}{|c|c|c|c|}
\hline & Value & Df & $\begin{array}{c}\text { Asymptotic significance } \\
\text { (2-sided) }\end{array}$ \\
\hline Pearson's chi-square & $253,545^{\mathrm{a}}$ & 16 &, 000 \\
\hline Likelihood Ratio & 217,746 & 16 &, 000 \\
\hline Linear-by-Linear & 133,500 & 1 &, 000 \\
\hline $\mathrm{N}$ of valid cases & 735 & & \\
\hline
\end{tabular}

Table 7. Lack of fluency.

ELIA Mon. I, pp. 235-264 DOI: http://dx.doi.org/10.12795/elia.mon.2019.i1.10 


\section{Poor vocabulary in English is an obstacle}

In the same way, poor vocabulary is also an obvious obstacle for holding a conversation in English as 63,2\% of the informants manifest. As expected, the higher the informant's level of English, the lower the concern about the lack of vocabulary (table 8).

\begin{tabular}{|c|c|c|c|c|c|c|c|}
\hline \multicolumn{8}{|c|}{ Crosstabulation } \\
\hline \multirow{2}{*}{\multicolumn{2}{|c|}{$\begin{array}{c}\text { Count } \\
1,0\end{array}$}} & \multicolumn{6}{|c|}{ Poor vocabulary in English } \\
\hline & & 2,0 & 3,0 & 4,0 & 5,0 & Total & \\
\hline \multirow[t]{2}{*}{ Level of spoken English } & 1,0 & 4 & 6 & 14 & 13 & 39 & 76 \\
\hline & 2,0 & 7 & 10 & 33 & 46 & 76 & 172 \\
\hline \multicolumn{4}{|l|}{$\begin{array}{c}3,0 \\
11 \\
18\end{array}$} & 47 & 60 & 49 & 185 \\
\hline & 4,0 & 25 & 44 & 53 & 52 & 27 & 201 \\
\hline & 5,0 & 41 & 16 & 21 & 12 & 11 & 101 \\
\hline \multicolumn{2}{|l|}{ Total } & 88 & 94 & 168 & 183 & 202 & 735 \\
\hline
\end{tabular}

Table 8. Level of spoken English * poor vocabulary.

Chi-square test indicates that there is a dependent relationship ( $p$-value $=0,000$ ) between the informant's level of spoken English and their concern about the lack of vocabulary, as could be expected without testing.

\section{Using English in conversations involving emotions (love, anger, sadness, feeling of helplessness, despair, etc.).}

Emotions are inherent to human beings. The way we express emotions might differ from one language to another, but also among individuals. Each person needs to express him/herself completely and satisfactorily adjusting the message to the addressees (Dewaele, 2010). Expressing emotions like anger or sadness in a foreign language can be accompanied by gestures, but this study aims to find out whether informants find it

ELIA Mon. I, pp. 235-264 DOI: http://dx.doi.org/10.12795/elia.mon.2019.i1.10 
difficult to stick to the foreign language when participating in a conversation with their children when emotions are intense. According to Dewaele (2010), especially concerning anger, L1 is preferred.

$79,8 \%$ of the informants state that maintaining English in a conversation which is emotionally intense when the participants are not native speakers to be a real challenge (table 9). In general, informants tend to consider it a great endeavour, as chi-test show $\mathrm{p}$-value $=0,001$, meaning the categorical variables are dependent. This implies that maintaining English as the language in use when the conversation is emotionally intense depends on the informant's level of English (table 9).

\begin{tabular}{|c|c|c|c|c|c|}
\hline \multicolumn{2}{|c|}{} & Frequency & Percent & Valid percent & $\begin{array}{c}\text { Cumulative } \\
\text { percent }\end{array}$ \\
\hline \multirow{7}{*}{ Valid } & 1,0 & 82 & 11,2 & 11,2 & 11,2 \\
\cline { 2 - 6 } & 2,0 & 66 & 9,0 & 9,0 & 20,1 \\
\cline { 2 - 6 } & 3,0 & 188 & 25,6 & 25,6 & 45,7 \\
\cline { 2 - 6 } & 4,0 & 176 & 23,9 & 23,9 & 69,7 \\
\cline { 2 - 6 } & 5,0 & 223 & 30,3 & 30,3 & 100,0 \\
\cline { 2 - 6 } & Total & 735 & 100,0 & 100,0 & \\
\hline
\end{tabular}

Table 9. Using English as an L2 in emotionally intense conversations.

\section{To make use of a foreign language in order for it to feel natural}

During a process of informal trial-and-error previous to the study aiming to select the possible variables and questions for the questionnaire, one of the most recurring comments made by the informants referred to the lack of "naturalness" when speaking a foreign language to their children. Results indicate that $74 \%$ of the informants (table 10 ) do agree, partially or totally, that it is a real challenge.

ELIA Mon. I, pp. 235-264 DOI: http://dx.doi.org/10.12795/elia.mon.2019.i1.10 


\begin{tabular}{|c|c|c|c|c|c|}
\hline \multicolumn{2}{|c|}{} & Frequency & Percent & Valid percent & $\begin{array}{c}\text { Cumulative } \\
\text { percent }\end{array}$ \\
\hline \multirow{7}{*}{ Valid } & 1,0 & 125 & 17,0 & 17,0 & 17,0 \\
\cline { 2 - 6 } & 2,0 & 66 & 9,0 & 9,0 & 26,0 \\
\cline { 2 - 6 } & 3,0 & 189 & 25,7 & 25,7 & 51,7 \\
\cline { 2 - 6 } & 4,0 & 162 & 22,0 & 22,0 & 73,7 \\
\cline { 2 - 6 } & 5,0 & 193 & 26,3 & 26,3 & 100,0 \\
\cline { 2 - 6 } & Total & 735 & 100,0 & 100,0 & \\
\hline
\end{tabular}

Table 10. Use of a foreign language with children as something 'natural'.

Pearson's chi-square test demonstrates that there is a relationship of dependence ( $p$-value $=0,002$ ) between the informants' level of English and whether or not they feel that using a foreign language is something natural while raising their children. Nonetheless, score distribution is interesting. Those informants who can't speak English score low, however, the same happens with those who can speak English at a C2 level (table 11).

\begin{tabular}{|c|c|c|c|c|c|c|c|}
\hline \multirow{3}{*}{ Count } & \multicolumn{7}{|c|}{ Crosstabulation } \\
\cline { 2 - 8 } & \multicolumn{6}{|c|}{ Making English feel 'natural' when speaking to my child } \\
\cline { 2 - 8 } & & 1,0 & 2,0 & 3,0 & 4,0 & 5,0 & Total \\
\hline $\begin{array}{c}\text { What's your } \\
\text { level of } \\
\text { spoken } \\
\text { English? }\end{array}$ & 1,0 & 14 & 3 & 20 & 12 & 27 & 76 \\
\cline { 2 - 8 } & 2,0 & 22 & 16 & 44 & 34 & 56 & 172 \\
\cline { 2 - 8 } & 3,0 & 33 & 14 & 53 & 43 & 42 & 185 \\
\cline { 2 - 8 } & 4,0 & 33 & 25 & 53 & 58 & 32 & 201 \\
\hline & 5,0 & 23 & 8 & 19 & 15 & 36 & 101 \\
\hline Total & 125 & 66 & 189 & 162 & 193 & 735 \\
\hline
\end{tabular}

Table 11.Level of English * use of English with the children as 'natural'.

ELIA Mon. I, pp. 235-264 DOI: http://dx.doi.org/10.12795/elia.mon.2019.i1.10 


\section{Being persistent in the use of English throughout the years}

We found interesting to analyse the informants' perception about perseverance throughout the years and the possibility of giving up the challenge of raising children bilingually in a foreign language (King \& Fogle, 2009). 88,7\% do agree, partially or totally, that it is a difficulty (table 12).

\begin{tabular}{|c|c|c|c|c|c|}
\hline \multicolumn{2}{|c|}{} & Frequency & Percent & Valid percent & $\begin{array}{c}\text { Cumulative } \\
\text { percent }\end{array}$ \\
\hline \multirow{7}{*}{ Valid } & 1,0 & 47 & 6,4 & 6,4 & 6,4 \\
\cline { 2 - 6 } & 2,0 & 36 & 4,9 & 4,9 & 11,3 \\
\cline { 2 - 6 } & 3,0 & 166 & 22,6 & 22,6 & 33,9 \\
\cline { 2 - 6 } & 4,0 & 214 & 29,1 & 29,1 & 63,0 \\
\cline { 2 - 6 } & 5,0 & 272 & 37,0 & 37,0 & 100,0 \\
\cline { 2 - 6 } & Total & 735 & 100,0 & 100,0 & \\
\hline
\end{tabular}

Table 12. Perseverance in raising bilingually.

There is a dependent relationship ( $p$-value $=0,009$ ) between the perception about perseverance in the long-term as a challenge and the informant's level of English. Those who can speak English at a B1 to C1 level score the highest. Thus, informants at a C2 level of spoken English are less worried about perseverance in the long-term (table 13).

\begin{tabular}{|c|c|c|c|c|c|c|c|}
\hline \multirow{3}{*}{ Count } & \multicolumn{7}{|c|}{ Crosstabulation } \\
\cline { 2 - 8 } & \multicolumn{6}{|c|}{ Being persistent in the use of English throughout the years } \\
\cline { 2 - 8 } & 1,0 & 7 & 4 & 17 & 15 & 33 & 76 \\
\hline \multirow{3}{*}{$\begin{array}{c}\text { What do you } \\
\text { think your level } \\
\text { of spoken } \\
\text { English is? }\end{array}$} & 2,0 & 8 & 7 & 42 & 40 & 75 & 172 \\
\cline { 2 - 8 } & 3,0 & 10 & 8 & 46 & 64 & 57 & 185 \\
\cline { 2 - 8 } & 5,0 & 10 & 12 & 44 & 74 & 61 & 201 \\
\hline Total & 12 & 5 & 17 & 21 & 46 & 101 \\
\hline
\end{tabular}

Table 13. Level of spoken English, perseverance as a challenge.

ELIA Mon. I, pp. 235-264 DOI: http://dx.doi.org/10.12795/elia.mon.2019.i1.10 


\section{Fear to negatively affect a child's peer relationships}

Any language opens a way of communication with other human beings. However, this might not be easy when children are raised in a language that is not the mother tongue of any of the parents or caregivers. Spanish children whose parents speak English to them without being native speakers of the English language, find themselves in a linguistic community in which English is neither the first nor the main language (L1). This can lead to a situation in which the possibilities of communication are diminished instead of enhanced by using a foreign language. Usually at the age of three the child begins school and socialises with his/her peers who are not used to speaking in English, and difficulties could arise. Nevertheless, results manifest that this is not a main concern for $70,9 \%$ of the informants (table 14).

\begin{tabular}{|c|c|c|c|c|c|}
\hline \multicolumn{2}{|c|}{} & Frequency & Percent & $\begin{array}{c}\text { Valid } \\
\text { percentage }\end{array}$ & $\begin{array}{c}\text { Cumulative } \\
\text { percentage }\end{array}$ \\
\hline \multirow{7}{*}{ Valid } & 1,0 & 373 & 50,7 & 50,7 & 50,7 \\
\cline { 2 - 6 } & 2,0 & 148 & 20,1 & 20,1 & 70,9 \\
\cline { 2 - 6 } & 3,0 & 130 & 17,7 & 17,7 & 88,6 \\
\cline { 2 - 6 } & 4,0 & 47 & 6,4 & 6,4 & 95,0 \\
\cline { 2 - 6 } & 5,0 & 37 & 5,0 & 5,0 & 100,0 \\
\cline { 2 - 6 } & Total & 735 & 100,0 & 100,0 & \\
\hline
\end{tabular}

Table 14. Fear to negatively affect a child's peer relationships.

Chi square test rejects dependence $(p$-value $=0,119)$ between the two categorical variables: the informant's level of spoken English and the fear of possible deterioration of peer socialisation due to the use of a foreign language.

\section{Social rejection}

Nowadays, we can hear Spaniards speaking English to their children anywhere, for instance, in a playground, at a café, or a restaurant. Spanish parents' use of English when raising their children is a new phenomenon in

ELIA Mon. I, pp. 235-264 DOI: http://dx.doi.org/10.12795/elia.mon.2019.i1.10 
Spain. This phenomenon is complicated by the fact that English is the mother tongue of none of the family members, who in addition live in a community where the language of use is different from the target language (TL). Therefore, we found it interesting to collect data concerning the fear of possible social rejection, bearing in mind that it is not uncommon to be afraid of the unknown or unusual as Nussbaum mentions (2011). In addition, bilingualism may not be well regarded in societies that tend to heterogeneity (Nussbaum, 2011).

Despite what we have stated, this study found that the aforementioned fear is a minor concern for $76,7 \%$ of the 735 families that have participated in the survey. Pearson's chi square test indicated that such a perception does not depend on the informants' level of spoken English ( $p$-value=0,386).

\section{Partner's commitment (if applicable)}

As it has been anticipated, this study includes diverse family structures. Informants have been asked to indicate how difficult it was for them to share a balanced commitment with their partners (if applicable) from 1 to 5 on a Likert scale. The resulting histogram displays an interesting distribution, with higher scores in the extremes and the central zone (figure $3)$. There is no dependent relationship $(p=0,024)$ between the partner's commitment and their level of English.

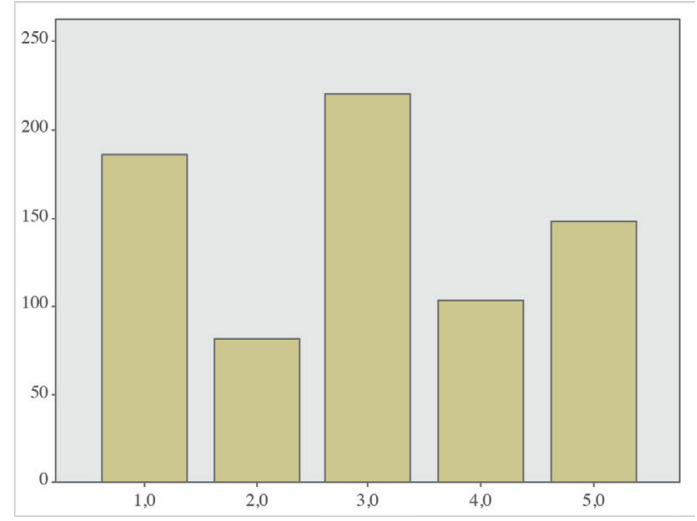

Figure 3. Shared commitment.

ELIA Mon. I, pp. 235-264 DOI: http://dx.doi.org/10.12795/elia.mon.2019.i1.10 


\section{Never using our mother tongue with our children}

'To stop using our language is to be silent' (Rodríguez Hernández, 2017: 38). Our mother tongue adheres to our soul and our unconscious, and it is expressed automatically. However, when we use a foreign language, we need to find the vocabulary and the closest expressions to the target language, but we might not reach the same level of exactness and accuracy as in our mother tongue (Rodríguez Hernández, 2017). Besides, some people who decide to use a foreign language when bringing up their children may feel nostalgic for not using their mother tongue with their children, since they have grown up using their mother tongue and it reminds them of their ancestors.

Taking the results into account, perceptions are diverse and do not depend ( $p$-value $=0,055$ ) on the informant's level of English.

\section{As a non-native speaker I cannot contribute positively to my child's level of English}

Finally, families were asked to indicate to what extent they agreed with the statement 'As a non-native speaker I cannot contribute positively to my child's level of English', scoring from 1 to 5 on a Likert scale. A 60,7 \% out of the 735 families that participated in this survey did not agree with such statement (table 15).

\begin{tabular}{|c|c|c|c|c|c|}
\hline \multicolumn{2}{|c|}{$\begin{array}{c}\text { As a non-native speaker I cannot } \\
\text { contribute to my child's level of } \\
\text { English }\end{array}$} & Frequency & Percent & $\begin{array}{c}\text { Valid } \\
\text { percent }\end{array}$ & $\begin{array}{c}\text { Cumulative } \\
\text { percent }\end{array}$ \\
\hline \multirow{7}{*}{ Valid } & 1,0 & 319 & 43,4 & 43,4 & 43,4 \\
\cline { 2 - 6 } & 2,0 & 127 & 17,3 & 17,3 & 60,7 \\
\cline { 2 - 6 } & 3,0 & 133 & 18,1 & 18,1 & 78,8 \\
\cline { 2 - 6 } & 4,0 & 85 & 11,6 & 11,6 & 90,3 \\
\cline { 2 - 6 } & 5,0 & 71 & 9,7 & 9,7 & 100,0 \\
\hline
\end{tabular}

Table 15. As a non-native speaker I cannot contribute positively to my child's level of English

ELIA Mon. I, pp. 235-264 DOI: http://dx.doi.org/10.12795/elia.mon.2019.i1.10 
Results indicate that believing non-native speakers of the English language cannot contribute to their children's level of English depends on the informant's level of spoken English. This is due to the fact that ( $p$-value $=0,0)$ the higher the informant's level of English, the more confident they feel in their ability to speak English (table 15).

\begin{tabular}{|c|c|c|c|c|c|c|c|}
\hline \multicolumn{8}{|c|}{ Crosstabulation } \\
\hline \multicolumn{8}{|c|}{ Count } \\
\hline \multirow{2}{*}{\multicolumn{2}{|c|}{1,0}} & \multicolumn{6}{|c|}{$\begin{array}{c}\text { As a non-native speaker I cannot contribute to } \\
\text { my children's level of English }\end{array}$} \\
\hline & & 2,0 & 3,0 & 4,0 & 5,0 & Total & \\
\hline \multirow{5}{*}{$\begin{array}{c}\text { What level of spoken } \\
\text { English do you think you } \\
\text { have? }\end{array}$} & 1,0 & 19 & 10 & 19 & 8 & 20 & 76 \\
\hline & 2,0 & 45 & 34 & 45 & 28 & 20 & 172 \\
\hline & 3,0 & 65 & 31 & 39 & 30 & 20 & 185 \\
\hline & 4,0 & 110 & 40 & 26 & 17 & 8 & 201 \\
\hline & 5,0 & 80 & 12 & 4 & 2 & 3 & 101 \\
\hline \multicolumn{2}{|l|}{ Total } & 319 & 127 & 133 & 85 & 71 & 735 \\
\hline
\end{tabular}

Table 16. Level of spoken English * contribution to the child's level of English.

\section{Conclusions and Implications}

Bringing up a child is a demanding and time-and-energy-consuming phase in life. On the other hand, using a foreign language also requires effort, concentration and attention. By bringing together both elements, we add extra challenges that are accompanied by myths or preconceived ideas that are worthy of analysis.

The impossibility of providing a native-like model of pronunciation may be a concern. Evidently, children learn to a great extent by imitation, and they are going to acquire the pronunciation and intonation they are exposed to. However, both pronunciation and intonation can be improved upon - even by self-learning - in the same way that vocabulary can be 
broadened; there are various books and methods for such purpose (Estebas Vilaplana, 2016) (Hancock, 2007).

Besides, do all teachers of English as a foreign language have a native-like pronunciation? Here again, the never-ending debate concerning the native speaker as the only model comes into play.

Another possible concern analysed is parent-child attachment. It seems that the attachment style is not negatively affected by bringing up a child bilingually in a foreign language. Love prevails over everything else when bringing up a child. 'Knowing that my daddy and my mummy truly loved me is the only thing that leaves its mark' (De Acevedo, 2014: 24). Moreover, Krashen's affective filter theory states that the learner can get paralysed by the effects of anxiety when he/she feels negative emotions or finds himself or herself under pressure (Krashen, 1982) but such a situation does not usually take place in the family unit. Besides, according to Krashen, language acquisition is more effective than learning provided that the latter implies an extra intellectual effort (Schutz, 2017) and, certainly, the family's using the foreign language can, with time and perseverance, favour more moments of acquisition rather than learning. In fact, music, films and games are recommended as valuable resources in the foreign language class (Lin, 2008), elements that are naturally integrated in the household's dynamic or in family relationships.

As concerns code-mixing, it does not imply any problem but quite the contrary: switching languages within a unique conversation or phrase can be due to the inaccuracy or absence of an equivalent term (Richards \& Schmidt, 2013). Moreover, it can demonstrate a developed linguistic ability that consists in selecting the most appropriate term from both languages.

Regarding the challenges of raising a child bilingually in a language that is the mother tongue of neither parents nor caregivers, I wish to highlight the lack of scientific and academic literature. Further investigation is needed. Despite the lack of scientific rigour, blogs and fora on social media are a direct and immediate way of communication amongst families. These function as support groups where personal experiences are shared and are defined cooperatively, sharing strategies for bilingual upbringing by non-natives.

ELIA Mon. I, pp. 235-264 DOI: http://dx.doi.org/10.12795/elia.mon.2019.i1.10 
The higher the informant's level of spoken English, the lower the difficulty imposed by the lack of fluency and poor vocabulary. Fluency can be enhanced by practising time and time again with a child. When the foreign language does not meet parents' requirement of communication during moments of anger or despair, for instance, we can resort to using the mother tongue.

Possible social rejection as a consequence of bringing up a child bilingually is not a main concern. The true challenge is perseverance in the use of the foreign language throughout the years and in all situations. Not using the mother tongue with one's child can evoke nostalgic feelings, but it can also create a special bond amongst family members once a conscious decision is made.

Finally, we would like to highlight that native speakers should not be taken as the only desirable model since they tend to be idealised (Chacón Beltrán, 2017). As we have already mentioned, being native does not necessarily mean being educated or mastering the language. We could then mistakenly consider foreign speakers to be defective versions of the native speaker (Cook, 2016). On the other hand, 'perhaps the objective is not to sound native-like, but to be competent in English without losing our identity' (Chacón Beltrán, 2018).

Nevertheless, although uncommon, it cannot be denied that sometimes a native-like level can be acquired (Han, 2004). Therefore, by means of bilingual upbringing the best of both worlds can be achieved (Piller, 2001).

\section{Acknowledgements}

Above all, I would like to thank each of the 735 families that altruistically filled out the questionnaire. Many of them have also contributed with valuable insights that helped me to improve the questionnaire. Without them, this study would not have been possible.

Special thanks to my dear friend Joanna Belalcázar, for her support and patiently proofreading the first manuscript.

And, of course, with sincere thanks and gratitude to the two anonymous reviewers for their careful and critical reading of the manuscript, whose many insightful comments and suggestions helped improve and clarify this paper.

ELIA Mon. I, pp. 235-264 DOI: http://dx.doi.org/10.12795/elia.mon.2019.i1.10 


\section{Notes}

In order to delimit a specific context with a concrete educational system this study purposely addresses the Spanish community in Spain.

\section{References}

Baker, C. (2011). Foundations of Bilingual Education and Bilingualism (Vol. 79). Clevedon. England: Multilingual Matters.

Bowlby, J. (1951). Maternal care and mental health (Vol. 2). Geneva: World Health Organization.

Brown, H. (2000). Principles of Language Learning and Teaching (4th ed.). Englewood Cliffs, N.J.: Prentice-Hall.

Chacón Beltrán, R. (2017). El "hablante nativo" de la lengua meta: ¿Qué importancia tiene para enseñar la L2? ELIA, Estudios de Lingüística Inglesa Aplicada [S.L.](1), 9-21.

Chacón Beltrán, R. (30 de noviembre de 2018). Whose English to teach in bilingual contexts? Ponencia: International Conference on Bilingualism and Interculturality: Challenges, Limits and Solutions. Madrid: UNED.

Chacón-Beltrán, R. (2018). The effects of intensive naturalistic exposure for children in pre-and post-literacy development. Complutense Journal of English Studies, 26, 219-239. https://doi.org/10.5209/CJES.58551

Cook, V. (2016). Where is the native speaker now? TESOL Quarterly 50(1), 186-189.

De Acevedo, A. (2014). La buena crianza. Argentina: Grijalbo.

De Houwer, A. (2007). Parental language input patterns and children's bilingual use (Vol. 3). Applied Psycholinguistics. Recuperado el 25 de 12 de 2018, de https://search-proquest-com.ezproxy.uned.es/ docview/200952255? accountid $=1460$

Department of Education. (1995). White paper on education and training. Government Gazette. Recuperado el 10 de 11 de 2018, de http://europa.eu/ documents/comm/white_papers/pdf/com95_590_en.pdf.

Dewaele, J. (2010). Emotions in multiple languages. Springer. https://doi. org/10.1057/9780230289505

ELIA Mon. I, pp. 235-264 DOI: http://dx.doi.org/10.12795/elia.mon.2019.i1.10 
Díaz Novás, J., \& Gallego Machado, B. (2014). Aforismos, proverbios, lemas y consejos (X). Revista Cubana de Medicina General Integral(30 (1)), 144148.

Estebas Vilaplana, E. (2016). Teach yourself English pronunciation: An interactive course for Spanish speakers ( $1^{a}$ reimp. ed.). Madrid: Netlibro.

Ghlamallah, Z. B. (abril de 2015). El profesor no nativo entre inseguridad y legitimidad. Recuperado el 1 de 1 de 2019, de cvc.cervantes.es: https://cvc. cervantes.es/ensenanza/biblioteca_ele/asele/pdf/26/26_0415.pdf

Han, Z. (2004). Fossilization in adult second language acquisition. Clevedon: Multilingual Matters. https://doi.org/10.21832/9781853596889

Hancock, M. (2007). English pronunciation in use: A self-study and classroom use (5th publ., 9th print. ed ed.). Cambridge University Press.

Illés, É. (2018). Matsuda, aya: Preparing teachers to teach english as an international language. Journal of English as a Lingua Franca(7 (2)), 411-414. http:// dx.doi.org.ezproxy.uned.es/10.1515/jelf-2018-0021

Jernigan, C. (2015). Family language learning: learn another language, raise bilingual children (Vol. 19). Multilingual Matters. https://doi. org/10.21832/9781783092819

King, K. A., \& Fogle, K. (2009). La crianza de niños bilingües: Preocupaciones comunes de los padres y las investigaciones actuales. Recuperado el 6 de 2 de 2019, de https://experts.umn.edu/en/publications/la-crianza-de-niÃ \pm osbiling $\tilde{\mathrm{A}} 1 / \mathrm{4}$ es-preocupaciones-comunes-de-los-padre

Krashen, S. (1982). Principles and practice in second language acquisition. New York: Prentice-Hall International.

Levy, M. (29 de noviembre de 2018). English Impact: The bilingual effect? Madrid: UNED.

Lin, G. H. (2008). Pedagogies Proving Krashen's Theory of Affective Filter. Obtenido de ERIC. Online submission: https://files.eric.ed.gov/fulltext/ ED503681.pdf

López García, L. (13 de julio de 2016). La interlengua y el análisis de errores en la adquisición de segundas lenguas. Distancia entre competencia y actuación. Obtenido de Repositorio Institucional Universidad de Oviedo: http://digibuo.uniovi.es/dspace/handle/10651/38554

Lozano-Martínez, L. (2017). Los docentes en los programas de educación bilingüe en Cantabria. ELIA: Estudios de Lingüistica Inglesa Aplicada (17), 93-124. https://doi.org/10.12795/elia.2017.i17.05

ELIA Mon. I, pp. 235-264 DOI: http://dx.doi.org/10.12795/elia.mon.2019.i1.10 
Myles, J. (2002). Second language writing and research: The writing process and error analysis in student texts. 1-20.

Nussbaum, M. C. (Vol. 18 de 2011). Libertad de conciencia: el ataque a la igualdad de respeto. Madrid: Katz ediciones.

Piller, I. (2001). Private language planning: The best of both worlds. Estudios de Sociolingüística (2 (1)), 61-80.

Richards, J. C., \& Schmidt, R. W. (2013). Longman dictionary of language teaching and applied linguistics. Harlow: Routledge. https://doi. org/10.4324/9781315833835

Rius, M. (28 de 12 de 2018). Estudiar en inglés: los beneficios de la educación bilingüe. La Vanguardia. Recuperado el 1 de enero de 2019, de https:// www.lavanguardia.com

Rodríguez Hernández, M. (5 de 10 de 2017). Dejar de hablar nuestra lengua es estar en silencio. Ecofronteras: Revista cuatrimestral de divulgación de la ciencia, 21(60), 38. Recuperado el 6 de enero de 2019, de http://revistas. ecosur.mx/ecofronteras/index.php/eco/issue/view/156

Sánchez Iglesias, J. J. (2011). Entre la fosilización y la evaluación: Viejos y nuevos aprovechamientos de los errores. Revista Nebrija De Lingüística Aplicada a La Enseñanza De Lenguas (10).

Sánchez Torres, J. (2010). Aspectos de la planificación lingüística de familias bilingües español/inglés en Sevilla. Elia: Estudios de lingüística inglesa Aplicada (10), 233-265.

Saunders, G. (1988). Bilingual Children: From Birth to Teens. Clevedon: Multilingual Matters.

Schutz, R. (12 de marzo de 2017). Stephen Krashen's Theory of Second Language Acquisition. Obtenido de English Made in Brazil.

Shepherd, E., \& Ainsworth, V. (2017). English Impact: An Evaluation of English Language Capability. Madrid: British Council.

White, L., \& Genesee, F. (1996). "How native is near native? The issue of ultimate attainment in adult second language acquisition.”. En Second Language Research (Vol. 12/3, págs. 233-265). https://doi.org/10.1177/026765839601200301

Zhao, H. (2018). An overview of research on family language planning. En Theory and Practice in Language Studies 8(5) (págs. 528-532.). https://doi. org/10.17507/tpls.0805.11

ELIA Mon. I, pp. 235-264 DOI: http://dx.doi.org/10.12795/elia.mon.2019.i1.10 


\section{Appendix}

\section{QUESTIONNAIRE (FRAGMENT)}

\section{INGLÉS E HIJOS}

¡Hola! Si tienes hijas o/e hijos y vives en España te invito a participar en este estudio sobre el aprendizaje y adquisición del inglés.

Contesta lo que piensas sin dejarte influir por lo que crees que deberías contestar o lo que se espera que contestes. Tu opinión sincera es muy valiosa, no hay respuestas correctas o incorrectas. Tu colaboración es muy interesante también si tus hijos/as están emancipados/as.

Los datos serán tratados de forma responsable y confidencial, respetando el Reglamento de Protección de Datos actual. Para cualquier duda o sugerencia contacta conmigo en bilingualbrotes@gmail.com.

Me comprometo a enviarte los resultados del estudio si así lo indicas al final.

Lleva entre 10 y 15 minutos.

¡MUCHAS GRACIAS!

Laura Lozano-Martínez

Investigadora en formación

Universidad Nacional de Educación a Distancia

$[\ldots]$

¿Qué nivel de inglés hablado consideras que tienes?

$\begin{array}{lllllll}\text { Ninguno } & 1 & 2 & 3 & 4 & 5 & \text { Experto o nativo }\end{array}$

$[\ldots]$

\section{MITOS}

¿Nos cuentas cómo concibes la crianza bilingüe?

El objetivo de la crianza bilingüe es alcanzar nivel de nativo en inglés *

En total desacuerdo

1

$\begin{array}{lllll}2 & 3 & 4 & 5\end{array}$

$\begin{array}{lllll}2 & 3 & 4 & 5\end{array}$

$\begin{array}{lllll}2 & 3 & 4 & 5\end{array}$

En total acuerdo

ELIA Mon. I, pp. 235-264 DOI: http://dx.doi.org/10.12795/elia.mon.2019.i1.10 
Mi pronunciación no nativa en inglés puede perjudicar el nivel de inglés de mi hijo/a *

En total desacuerdo

En total acuerdo

$\begin{array}{lllll}1 & 2 & 3 & 4 & 5\end{array}$

Los errores que yo cometo mi hijo/a los fijará (fosilizará) de forma que será difícil corregirlos *

En total desacuerdo

En total acuerdo

$\begin{array}{lllll}1 & 2 & 3 & 4 & 5\end{array}$

La relación entre p/madre e hijo/a puede verse entorpecida por la crianza en una lengua no materna *

En total desacuerdo

En total acuerdo

$\begin{array}{lllll}1 & 2 & 3 & 4 & 5\end{array}$

Si mi hijo/a mezcla el inglés y el español es que algo va mal *

En total desacuerdo

En total acuerdo
1
2
3
4
5

Al no ser nativo no puedo contribuir al nivel de inglés de mi/s hijo/a/s * En total desacuerdo

En total acuerdo

$\begin{array}{lllll}1 & 2 & 3 & 4 & 5\end{array}$

$[\ldots]$

\section{RETOS}

Ahora cuéntanos cuáles te parecen las mayores dificultades al criar hijo/a/s bilingües sin ser nativo/a

La falta de fuentes de información sobre cómo llevarlo a cabo * En total desacuerdo

En total acuerdo

$\begin{array}{lllll}1 & 2 & 3 & 4 & 5\end{array}$

ELIA Mon. I, pp. 235-264 DOI: http://dx.doi.org/10.12795/elia.mon.2019.i1.10 
La falta de vocabulario en inglés *

En total desacuerdo

$1 \quad 2 \quad 3$
En total acuerdo

4

5

La falta de fluidez en inglés *

En total desacuerdo

En total acuerdo

1

2

3

4

5

Usar el inglés en conversaciones con carga emocional (cariño, enfado, tristeza, ira, etc.) *

En total desacuerdo

En total acuerdo

1

2

3

4

5

Que hablar con mi/s hijo/a/s en una lengua extranjera se convierta en algo 'natural' *

En total desacuerdo

En total acuerdo

$\begin{array}{llllll}1 & 2 & 3 & 4 & 5\end{array}$

Ser constante en el uso del inglés a lo largo de los años *

En total desacuerdo

En total acuerdo

$\begin{array}{llllll}1 & 2 & 3 & 4 & 5\end{array}$

El miedo a perjudicar las relaciones de mi hijo/a con los de su edad (socialización entre iguales) *

En total desacuerdo

En total acuerdo
1
2
3
4
5

El rechazo de algunas personas *

En total desacuerdo

En total acuerdo

1

$2 \quad 3$

4

5

Que la pareja (si es el caso) se implique al mismo nivel *

En total desacuerdo

En total acuerdo

$\begin{array}{lllll}1 & 2 & 3 & 4 & 5\end{array}$

ELIA Mon. I, pp. 235-264 DOI: http://dx.doi.org/10.12795/elia.mon.2019.i1.10 
No usar nunca mi lengua materna o principal con mi/s hijo/s

En total desacuerdo

En total acuerdo

1

2

3

4

5

$[\ldots]$

First version received: August, 2019

Final version accepted: November, 2019

ELIA Mon. I, pp. 235-264 DOI: http://dx.doi.org/10.12795/elia.mon.2019.i1.10 